\title{
Research Proposal: Detecting the Level of Chemistry Competence and Study Skills in First Year Health Science Students
}

\author{
Marambio, L.; Zacconi, F. C.
}

Rev. Virtual Quim., 2015, 7 (3), 928-934. Data de publicação na Web: 3 de maio de 2015

http://www.uff.br/rvq

\section{Proposta de Pesquisa: Detectar o Nível de Competências em Química e Habilidades de Estudo de Ingressantes da Escola de Ciências da Saúde}

Resumo: O presente trabalho apresenta os resultados preliminares de um estudo em andamento que é baseado em uma pesquisa onde é perguntado sobre o envolvimento prévio dos estudantes com a química do ensino médio e suas expectativas em relação à química vista na universidade. Este estudo irá detectar as competências e habilidades, especificamente na área de Química, que os alunos do primeiro ano de diversos cursos de Ciências da Saúde devem possuir ao entrar na universidade.

Palavras-chave: Competências; química; ciências da saúde.

\begin{abstract}
The following work shows the preliminary results of a study in progress which is based on a survey that asks about the students' previous involvement in high school chemistry and their expectations regarding university level chemistry. This study will detect the competence and skills, specifically in the area of Chemistry, that first year students from diverse Health Sciences majors possess upon entering the university.
\end{abstract}

Keywords: Study skills; chemistry; health sciences.

\footnotetext{
* Pontificia Universidad Católica de Chile, Facultad de Química, Vicuña Mackenna, 4860, Macul 78204336, Región Metropolitana, Santiago, Chile.

M fzacconi@uc.cl

DOI: $10.5935 / 1984-6835.20150049$
} 


\title{
Research Proposal: Detecting the Level of Chemistry Competence and Study Skills in First Year Health Science Students
}

\author{
Leonor Marambio, ${ }^{a}$ Flavia C. Zacconi ${ }^{\mathrm{b}, *}$ \\ ${ }^{a}$ Universidad Finis Terrae, Facultad de Educación y Ciencias de la Familia, Pedro de Valdivia \\ 1509, Providencia 7501015, and Departamento de Ciencias Biológicas y Químicas de la \\ Facultad de Ciencia Universidad San Sebastián. Región Metropolitana, Santiago, Chile. \\ ${ }^{\text {b }}$ Pontificia Universidad Católica de Chile, Facultad de Química, Vicuña Mackenna, 4860, Macul \\ 78204336, Región Metropolitana, Santiago, Chile. \\ * fzacconi@uc.cl
}

Recebido em 3 de maio de 2015. Aceito para publicação em 3 de maio de 2015

\section{Introduction}

\section{Objectives}

\section{Preliminary Project Development}

\section{Final Considerations}

\section{Introduction}

In this present article, we seek to point out the importance that is given to teaching based upon competencies in higher education at university. For this reason, gathering national and international information about Health Science major requirements has been fundamental with regard to teaching the minimal competencies that students must acquire for the study of Chemistry.

On the other hand, we want to present some of the concerns that we, teachers of chemistry from different universities, have. We continually remark upon the missing or the complete absence of skills in this discipline that we observe in new students. We understand that by only confirming this situation that we fall into the easiest solution. Make the high school teachers responsible for this situation. Nonetheless, upon analyzing, a little more deeply, the facts related to the lack of competence in Chemistry, we think it is necessary to answer questions such as:

1. What are the necessary Chemistry competencies for students in Health careers?

2. How do the children and young people of 2014 learn?

3. What competencies do we need new students to bring to Health careers?

4. How can universities support the formation of scientific competencies in schools? 
In order to give an answer to these questions, we have had to make an important bibliographical search. From out of diverse readings, the following paragraph surged forth like a cognitive break through:

"Then I understood the true magnitude of this new and radical generational struggle that is occurring in lecture halls, in homes, on the paths of modernity, on the podium, and among the columns. The problem, and it is not only pedagogical, is simply a deep generational duel between digital natives who come into the world with their bits in place and we digital immigrants, who are trying to recycle ourselves to the uses and customs of the new Galaxy." 1

XXI century students not only define themselves as digital natives, but also as technologized students, a term, which refers to the possibility of acquiring and using all of the available technological tools that today, more than ever, are within the reach of the majority of students.

Furthermore, young people are facing their education with the growing necessity to experiment with new forms of socialization (social networks, messaging services, internet calls, videos, animations, smartphone applications etc) associated with Information and Communication Technologies (ICT).

The education in which they find themselves immersed provides them with experiences, values, and attitudes that allow them to actively participate in new social environments that are becoming for many of them the school, the university, or institute, the only space where they learn the indispensable competencies and skills for their personal and professional development.

XXI century competencies and skills are related to a country or region's economic development in which the pertinent educational development is found developing. Consequently, the authorities, institutions, and professors must commit themselves to identifying and conceptualizing the skills and competencies necessary according to educational standards. This will be achieved through the means by which the educational systems and curriculums are incorporated, reinforced, and evaluated by the authorities in each particular area.

Keeping in mind that the skills and competencies to be achieved are important, and this must be in accordance with the specific knowledge necessary for development and understanding of traditional concepts; because if the student is missing the appropriate knowledge, he runs the risk of omitting, confusing, or not understanding the concept in its totality.

The definitions of skill and competency are interrelated, a useful differentiation between the two is present in the DeSeCo Project (Definition and Selection of Competencies):

"A competence is more than just knowledge or skills. It involves the ability to meet complex demands, by drawing on, and mobilizing psychosocial resources (including skills and attitudes) in a particular context. For example, the ability to communicate effectively is a competence that may draw on an individual's knowledge of language, practical IT skills, and attitudes towards those with whom he or she is communicating". ${ }^{2}$

Alternatively, the European Parliament defines a competence (technical abilities, social skills, use of theory, and knowledge) as a broad concept from which skills are composed:

"Competencies are defined as a combination of adequate knowledge, abilities, and attitudes within a given context. Key competencies are those that everyone has to have for their personal growth and development, as well as for active citizenship, social inclusion, and employment." ${ }^{3}$

Study in the field of Chemistry related to Health Science careers, and the use of appropriate skills and competencies will be reflected in a student who has achieved mastery of these competencies; however, they will be missed in another student, who lacks mastery of these competencies, and who will not only be affected during his university career, but also in his professional 
future.

The diverse transformations, which have occurred regarding the desired level of demand; the educational paradigm shift centered on the student, and oriented towards life after university studies has made professors confront each day with the interest and obligation of achieving quality education that impacts the student's culture, with the objective of not only complying with a program of study, but also achieving scientific literacy.

Moreover, it is important to mention that competencies do not substitute for the elements presented in the curriculum. They cannot be directly evaluated, nor are they independent from one another, rather they are interrelated.

This present work consists of a preliminary study of Chemistry competencies and skills present in first year students in Health Science careers. What material from Chemistry should we professors impart, improve, or expand to achieve a quality professional education whose impact becomes a support for society. ${ }^{4}$

This project surges forth from a necessity to find an answer to diverse existing problems: students have difficulty when they communicate or express concepts or ideas, as well as having a low tolerance for failure. Furthermore, students are not prepared to wait, make mistakes, or persist until they understand the concepts involved in the curriculum.

\section{Objectives}

During the course of the project that we are developing, we consider it important to support scholastic formation by detecting the level of Chemistry education in first year university students with respect to their achievements in different areas such as cognitive, procedural, and attitudinal competencies.
In addition, with the results obtained, we are able to establish teaching strategies at the university level that permit students to acquire a better disciplinary advantage in their academic formation, by giving support to a larger sphere of professors relative to the most required skills for students' adequate initial formation in Chemistry for Health Science careers.

\section{Preliminary Project Development}

Based on studies carried out by the authors using diverse tools such as surveys, written evaluations, workshops, tutorials, and oral exams, 400 students from diverse Health Science careers such as Obstetrics, Nutrition, Kinesiology, Dentistry, and Medicine have been observed. The first year that the necessary cognitive competencies for Chemistry studies for Health Sciences were surveyed included around $25 \%$ of the necessary learning concepts.

However, the most significant deficit does not reflect whether they possess or not disciplined knowledge, rather that they lacked soft skills such as communication, investigation, and study techniques, as well as scientific thinking that would allow them to quickly and effectively overcome their lack of conceptual content. ${ }^{5}$

With the aim of performing a study in stages over the course of two years of investigation, a previous survey of four simple questions has been carried out on the first day of classes. Health Science majors are asked to respond to the questions without prior judgment regarding the relevant Chemistry curriculum.

The survey performed the following questions: 
1. Who had Chemistry during their four years in High School?

2. Who had two years of Chemistry in High School?

3. Who has seen all the program content that will be taught during your university education?

4. Who thinks they are prepared to successfully finish this course?
The results of the survey will indicate to us the student expectations with respect to their entry into Chemistry. In addition, the same survey will be repeated at mid-term and at the end of the semester.

The results of the survey are shown in the following graph (Figure 1):

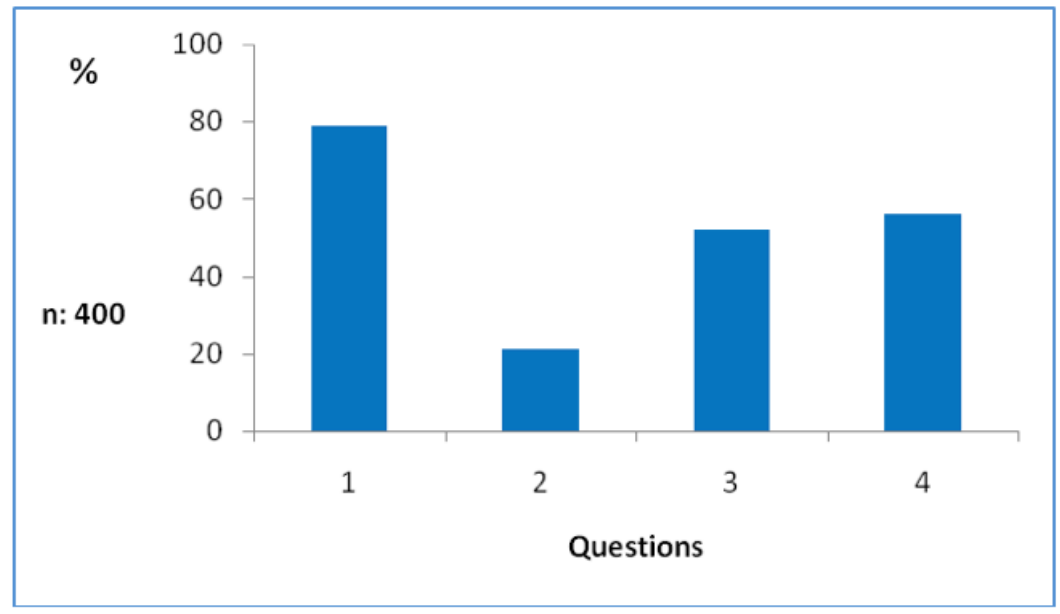

Figure 1. Results of the survey with 400 students from diverse Health Science careers such

While $79 \%$ of the students affirmed that they had attended Chemistry classes during their four years of High School, only $52 \%$ had contact with all the subjects necessary to fully develop the material. It must be considered that the Chemistry taught during the first year for these careers contemplates $80 \%$ knowledge of the syllabus assigned during the course of High School. Moreover, $56 \%$ of students consider that they will finish the course successfully, even when they haven't encountered all the necessary subjects (Figure 1 ).

Complementing the first survey another small survey was carried out with questions about diverse topics, to collect data with respect to the methodologies that the Chemistry professors used in the High Schools, with the objective of detecting relationships among applied methodology, learned concepts, and developed skills.
1. Did the Chemistry professor use any of the available technologies for teaching the material? For example: videos, internet links, web pages, or presentations

2. Did you work on experiments in the laboratory or classroom?

3. Did you do any research in conjunction with the Chemistry subjects developed during High School?

4. Did you give science presentations in front of classmates or other kinds of audiences?

According to the results of the questions (Figure 2), we can infer that fewer than $50 \%$ of the students have been taught using XXI century teaching methodologies. These methodologies are found in Ministry of Education of Chile programs and are a relevant complement to developing Chemistry teaching strategies for those students who are digital natives. 


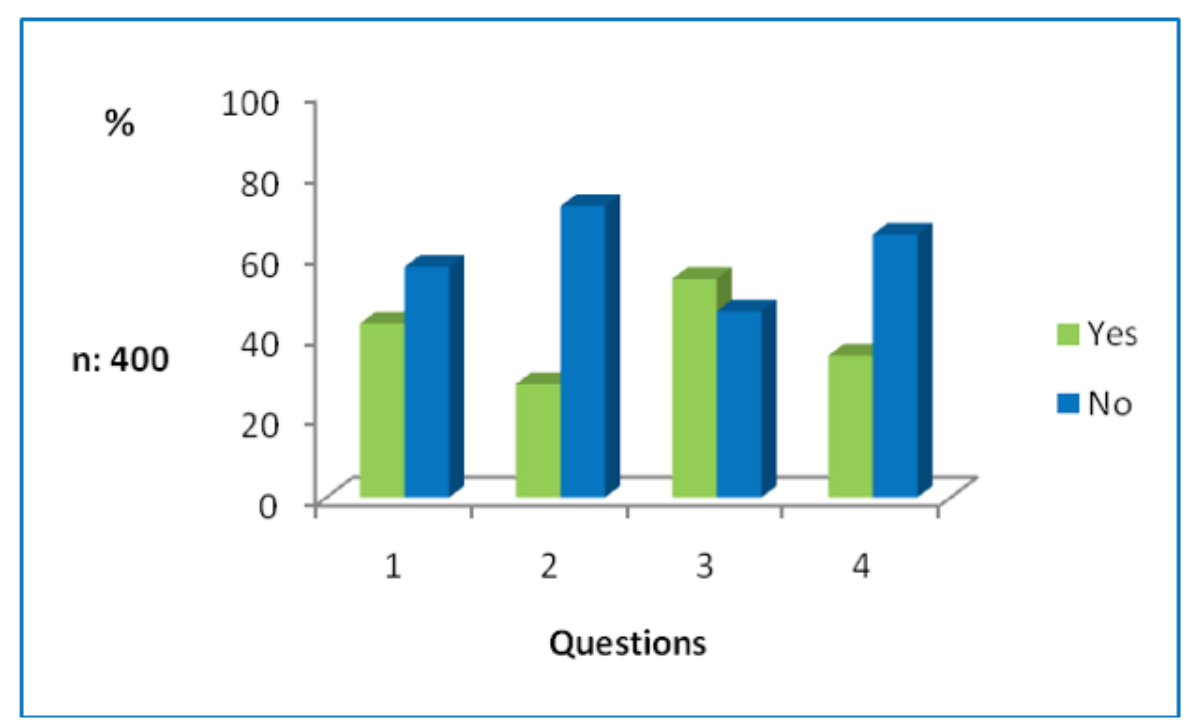

Figure 2. Results of the questions of the survey

Even though, the study programs contemplate the use of necessary skills and competencies for these new students; gradually incorporating them, their use, and application is not yet reflected in High Schools on the part of the professors in charge of teaching them.

Moreover, it is important to mention that the students surveyed declared that they hadn't used available technologies in the investigation or development of Chemistry in the High School, and only performed if it was an obligatory task where the activity was rewarded with a grade additional to the classical activities performed.

\section{Final Considerations}

Those of us, who work with first year university students, realize the competencies derived from Chemistry, which require a competent level especially for Health Science careers, are those which allow the development of scientific thinking. The achievement of these competencies is absolutely necessary, thus scholastic formation of students should begin during basic education, ideally in pre-school, and develop in the first years of curiosity which will be able to orient learning throughout all the following school years.

Keeping in mind the preliminary results of this study, we wish to manifest that today's education must teach students how to learn during the High School years, so that first year university students will need less time to successfully adapt to the university system. On the other hand, participation in scholastic formation in the academic world is a responsibility that few universities adopt. For example: the Chemistry Faculty at the Pontificia Universidad Católica de Chile is developing a proposal called Penta UC. Penta $U C$ is a faculty activity that invites High School students to visit the laboratories. This is an initiative that helps to develop these competencies; nevertheless, the scholastic universe encompassing such endeavors is very small.

In highlighting the importance of first year university teaching strategies, we should aim more towards teaching competency than content. This would generate a course in which we would teach students to relate Chemistry's own subjects and concepts to their career and not continue teaching Chemistry in a "hard" way, as if its content were the only heritage of Chemistry. 


\section{Acknowledgements}

Our thanks to the Chemistry Faculty at the Pontificia Universidad Católica de Chile (PUC), to the Faculty ofEducación y Ciencias de la Familia de la Universidad Finis Terrae (UFT) and to the students involved in the study.

\section{References}

${ }^{1}$ Cueto, J. Esos nativos digitales. Available at: $<$ http://elpais.com/diario/2007/06/24/eps/1 182665755 850215.html>. Acessed on: 19 may 2014.

${ }^{2}$ Website of the OECD iLibrary EDU Working paper $\mathrm{N}^{\circ} 41$. Available at: <http://www.oecdilibrary.org/education/oecd-educationworking- papers 19939019;jsessionid=8bhesf0gdtmt.d elta?page=2>. Acessed on: 19 may 2014.

${ }^{3}$ Website of the Centre of the Republic of Slovenia for Movility and European Educational and Training Programmes. Recommendation of the european parliament and of the council of 18 December 2006 on key competences for lifelong learning.Available at: $<$ http://www.cmepius.si/en/>. Acessed on: 23 may 2014.

${ }^{4}$ Website of the Ministerio de Educación de Chile. Available at: <http://www.mineduc.cl/> Estándares orientadores para carreras de pedagogía en educación media. Acessed on: 19 june 2014. ${ }^{5}$ Hernández, S. A.; Zacconi, F. C. M.; Alfabetización científica: una mirada desde la disciplina química, 1a. ed., EAE: Alemania, 2012. 